Brisset, F. (2014). Yinglish in Woody Allen's films: A dubbing issue. Linguistica Antverpiensia, New Series. Themes in Translation Studies, 13, 112-134.

\title{
Yinglish in Woody Allen's films: A dubbing issue
}

\section{Frédérique Brisset}

Université Lille 3 - Charles de Gaulle, France

frederique.brisset@univ-lille3.fr

A prominent representative of the Jewish-American population, Woody Allen often refers to his Ashkenazi origins in his films in a self-derisive way. His dialogues are interspersed with Yinglish, a feature which offers a serious challenge to French translators, especially for the dubbed versions of the films. Dubbing remains the prevalent mode of audiovisual translation in France and provides many opportunities to manipulate and alter the original film soundtrack. This article presents a comparative analysis of examples from Allen's dialogues and the French dubbed versions, in an attempt to unearth the strategies used by translators in view of adapting to the diverging abilities of the target audience. Two semantic fields are under scrutiny: the religious Jewish technolect and Yiddish slang, a humorous device which serves the needs of protagonist characterization and is widely assimilated by American English. The examples are taken from eight comedies by Allen, covering a thirty-fouryear time span in the director's extensive career.

\section{Introduction}

Designed to convey foreignness, multilingualism in films can be most obvious when the diegesis is set in more than one country, when the film stages foreign characters abroad, or when the protagonists happen to be true polyglots. A famous example at this point in time is Inglourious Basterds (Tarantino, 2009). Yet multilingualism may also be concealed in one's usual environment. The American language bears testimony to this socio-linguistic phenomenon, for it has integrated an impressive number of loanwords from many other languages, for technical purposes or as a means of responding to specific communication needs.

A place where the borrowing process is made visible is the film screen. According to Hitchings (2009): "What, though, makes a loanword stick? (...) Those that endure are the ones that are useful, deal with matters of lasting significance, and achieve a high level of exposure" (p. 19). Therefore, when writers such as Woody Allen decide to include Yiddish loanwords in their scripts, they rely on the spectators' familiarity with this specific lexicon, which may thus, paradoxically, not be so specific. For dialogues are conceived by authors according to peculiar 
constraints, as highlighted by Bubel (2008): "Understanding is possible on the basis of knowledge, shared between speaker and listener" (p. 63).

We resort in this paper both to the reception-aesthetics theories outlined by Jauss in his seminal works in the 1970s and further developed by Eco (1992, pp. 52-67), and to the theory of deforming tendencies in translation (Berman, 1999, pp. 52-54). Reception theories are particularly relevant as far as movies are concerned, because cinema is not only a form of art but also an industry for which the reception process is determining, first of all on the economic level.

This article presents the main lexical features of Yinglish - the dialect also presents a number of specific syntactic and phonological features which are not examined here — and considers its most outstanding two lexical fields in some of Woody Allen's numerous films: the religious technolect and slang. The study is based on eight comedies covering a 34-year span in the writer-director's prolific career. What happens to these two lexical fields when dubbed into a foreign language such as French is then analyzed, using transcriptions made from the DVDs and the published film scripts. Special attention is given to the circumstances under which the examined features are either translated or preserved, and the consequences induced by the translators' choices; this reveals the constraints for the transfer of multilingualism onscreen. Indeed, the strategy that consists in subtitling the lines spoken by a foreign character within an otherwise monolingual context cannot be applied to isolated words or expressions in a dubbed version, since the risk of breaking the conversation flow would be too great.

\section{Yinglish for schmucks}

Yiddish is spoken by some four million people around the world. It is nowadays well established in North America, to the point that a compound variety, Yinglish, is commonly recognized and spoken by American (Ornstein-Galicia, 1989) and Canadian (Gold, 2002) people. The Merriam-Webster online dictionary defines it as "English marked by numerous borrowings from Yiddish" and dates the first registered use of the word back to 1951. However, the overall situation differs in Frenchspeaking countries, where no such portmanteau noun can testify of a compound variety of Yiddish-tinged lingo.

Demographic and cultural differences in the two geographical spheres can explain this uneven state of affairs. France has always promoted a complete integration of ethnic minorities in its inclusive Republic, while the United States has so far preserved the rights of "hyphenated" citizens ${ }^{1}$ to express their double identity in its multicultural society, even though the well-known American demographic integration process is known as the "melting-pot". Meanwhile, in practice, things are not so clear-cut. 
Yinglish results from the contact between Yiddish and American English, which first occurred in the late 1880s at a time when great waves of Ashkenazi Jews emigrated from Eastern Europe. As a result, two and a half million Jews turned American citizens in the late 19th and early 20th centuries (Hitchings, 2009, p. 258). Most of them settled in the main cities of the East coast. The most recent estimates of the Jewish American population stand at 5,425,000. In New York alone, they were 1,538,000 in 2011, according to the United Jewish Appeal, that is, $16 \%$ of the city's population.

However, these ratios do not account on their own for the cultural impact of the Jewish group, which is due to its people's influence in the media and entertainment industries. Another relevant feature is the presence in their ranks of celebrated writers such as Paul Auster, Saul Bellow, Norman Mailer, Bernard Malamud, Cynthia Ozick and Philip Roth, to name but a few.

Last but not least, a further explanation for the easy transfer from Yiddish to American lies in the German ancestry common to both languages, for Yiddish may be described as a blend of Hebrew and German. As a result, "millions of English-speakers with no Jewish connections are familiar with (...) distinctively Yiddish expressions" (Hitchings, 2009, p. 260). This led to many Yinglish words, now registered in contemporary American dictionaries.

\section{Hyphenated Woody}

Woody Allen, as a writer, director and actor, is recognized as one of the most influential broadcasters of Yiddishisms, along with comedians such as Larry David, Jerry Seinfeld and Lenny Bruce. He was born in the Bronx but grew up in Brooklyn. His Jewishness is more cultural than religious and characteristics such as the use of Jewish humor and autobiographical material in many of his films pave the way towards Yinglish in the dialogues.

Allen's recurrent persona is reminiscent of the schlemiel, "an unlucky, bungling person; a foolish gullible person" (Webster's, 1966, p. 2030), who can be seen as the embodiment of the Jewish destiny as a whole, -Allen can even "elaborate the archetype into a hundred different subcategories, [starting with] the philosopher-schlemiel..." (Harris, 2009, p. 2). Like most Jewish descendants, his characters live usually in urban settings, more often than not in New York, from where many Jewish comedians also originated. Cities, which were the first and often final stage for immigrants, thus offer favorable conditions to the linguistic borrowing process; and this, even though many incomers were willing to forget their ethnic origins. The fact that "Jews long regarded Yiddish as a sort of lower-class jargon" (Hitchings, 2009, p. 258) led to a substantial 
proportion of vulgarisms in the language and those connotations stayed when some of the words integrated American English.

The structure of the language is also to be considered. As a linguistic device, "Yiddish has frequently been celebrated for being so rich in comic possibilities that even those who don't understand it are apt to chuckle at many of its terms" (Novak \& Waldoks, 1981, p. xvii). Allen is, mostly, the author of comedies, a genre that relies on witty dialogues, puns and jokes. In other words, it is no surprise that the language can frequently be heard in his films. Ornstein-Galicia (1992, p. 451) has summarized this particular use of Yinglish lexical items as affective borrowing.

\section{Technical Yinglish in use}

The first function of Yinglish can nevertheless be defined as a technical one, aiming at compensating for the lack of vocabulary for specific social occupations. In 1938, Roeback thus noted that Yiddish expressions abound in commerce, whether it be in the jewelry, furniture or shoe trades (quoted by Mencken, 1977, p. 260). Films rely heavily on mimesis and are much concerned with verisimilitude. The ability to imitate the ordinary day-to-day world in which the spectators live is essential to allow them to identify with the characters: "The 'authenticity' of fictional dialogue is widely held to play a pivotal role in shaping the audience's perception of the quality of a film" (Pérez-González, 2007, p. 1). Consequently, the professionals presented onscreen have to resort to the same lexicon as the one used in real life.

In Allen's movies, the main examples of Yiddish technolect are taken from the religious field. They occur during the ceremonies and family gatherings he often stages, such as Seders, Bar mitzvahs and High Holidays. We can foresee a translation issue with regard to these terms, for a very pragmatic reason:

Referents are resources employed by those who create fiction in order to characterize characters as individuals within a given social group, we can then postulate that scriptwriters must be confident that viewers will be able to recover the referential and expressive information associated with these referents (Santamaria, 2010, p. 516).

However, the vocabulary related to Judaic rituals has never been truly integrated into French. The words bar mitzvah, seder, or yarmulke, to take but three, are not listed in monolingual French dictionaries, not even in specialized ones like the Dictionnaire des difficultés du français (1996). How can that gap be explained?

First of all, France is a Latin country, whose language has few affinities with the Germanic origins of Yiddish. Secondly, the French 
Jewish community only accounts for an estimated $1 \%$ of the whole population, i.e. ten times fewer people than in the USA, many of them Sephardic Jews from North Africa. Thus, for a majority of Frenchspeaking citizens, the lexicon concerning historical, cultural and religious traditions, whether referring to rituals, ceremonies or sacraments, is often reduced to folklore, which epitomizes the status of Jewish people in the society as a whole. Indeed, "the borrowing process, actually, is capable of revealing much about inter-ethnic perceptions" (Ornstein-Galicia, 1989, p. 125). So, what happens to these loanwords when they have to be transferred into French? The contrastive analysis below aims to answer that question.

\subsection{Seder}

A seder is "a Jewish home or community service and ceremonial dinner held on the evening of the Passover" (Webster's, 1966, p. 2054). The noun was first borrowed from Hebrew. It occurs in Crimes and Misdemeanors, a 1989 film whose leading character, Judah, experiences a flashback when visiting his childhood home. He sees a family gathering where sister and brother are quarrelling.

OV, 67’30, Sol: May, we're having Seder!

DV, Sol : May, ce soir, c'est le Seder!

Further on, the quarrel continues.

OV, 67'40, Sol: I don't like this talk in my Seder!

DV, Sol : Je crois qu'on ne parle pas comme ça à mon Seder!

In addition, a third occurrence happens a few minutes afterwards:

OV, 68'20, Sol: How can you say that? You, you come to every Seder, you, you pray in Hebrew.

Al: Yes, I'm going through the motions, it's like any ritual, it's a habit!

DV, Sol: Comment tu peux dire ça? Toi qui ne manques jamais un Seder, toi qui dis les prières en hébreu.

Al : Je fais ça machinalement, c'est comme tous les rituels, c'est une habitude!

Although seder is not a loanword in French, the easy transfer can be explained by the visual context, a family dinner with candelabras set on the table, and men wearing yarmulkes, "a skullcap worn esp. by Orthodox and Conservative Jewish males, in the synagogue, the house, 
and study halls" (Webster's, 1966, p. 2647). In each of these utterances, the co-text also justifies the borrowing of the lexeme: the scene opens with Hebrew recitations over the meal and the conversation deals with the relevance of faith, Judaic rituals and their observance, as can be heard in the third occurrence. Moreover, in the second occurrence, the possessive adjective $m y$, which determines the noun and is stressed by the speaker, implies a very personal relation between the speaker and the seder ceremony. The target audience can be expected then to accept the foreign name in Sol's line, in French. The same thing happens in another film by Allen, Hollywood Ending, in 2002, which points to a consistent choice by Cohen, who translated all of Allen's films into French for subtitled and dubbed versions from 1989 to 2012.

This dubbing strategy does not impede the understanding of the plot or the progress of the story within the movie, and it helps maintain the original local color. In Crimes and Misdemeanors, keeping the exotic effect is essential as it sustains the dramaturgy. Judah's flashback vision has an unreal quality intended to create a feeling of unease in the film's audiences, and foreignisms such as seder contribute to that feeling of estrangement in the original version. They should indeed be kept in the dubbed one to provide the same dramatic effect.

In the case of dubbing, this strategy can even be reinforced by the translator, as shown by another example taken from Hollywood Ending (2002), when Al receives a call during the Seder dinner at his sister's. When the phone rings, the guests, filmed in a long shot, react most negatively, as reported in the original script (Allen, 2002, p. 104):

OV, 38'40, Seder guests: (indistinct, overlapping comments of disapproval - continues under following dialogue)

However, in the French version, Cohen has chosen to make the reactions much more explicit.

DV, Al : Oh, non, pas ce soir! Qui est-ce?

Voix 2 : Oh! Oh, qui peut t'appeler un soir de Seder?

This complete transformation of the soundtrack is made possible by the dubbing technique. Combined with the visual context, the change helps the audience to understand the exact nature of the dinner, where male guests are wearing yarmulkes. Thereby, it paves the way for the next line, spoken by Al, with the word seder now easily transferred into French.

OV, 38'50, Al: (into telephone) Why? What's wrong? I'm at my sister's for a Seder.

DV, Al : Quoi ? Qu'est-ce qui se passe? Je suis chez ma sœur pour le Seder. 
This manipulation is indeed an illustration of the relativity of the concept of foreignness. A word that was taken for granted for the American audience is considered so opaque for the French spectators that some additional information is deemed necessary in the co-text of the dialogue.

(...) nationality and cultural identity lie very much in the eye of the beholder. It is less something which exists per se than something constructed by the filmmaker, and re-appropriated by the audience (Mingant \& Tirtaine, 2012, p. 5).

This cultural identity construction process, which relies here on rituals, family gatherings and the use of a common Yinglish lexicon, is also made obvious in the example below.

\subsection{Bar Mitzvah}

In another movie by Allen, Scoop (2006), bar mitzvah celebrations are quoted by Sid Waterman, a professional magician aka The Great Splendini, played by Allen himself.

OV, 20', Sid: Listen, this is not for me, Sondra. I don't do this. I, I, I do the occasional Bar Mitzvahs and kids' parties...

A bar mitzvah is "the Jewish initiatory synagogue ceremony recognizing a boy [as having] attained the age of religious duty and responsibility" (Webster's, 1966, p. 177). The term is well established in American - the COCA, Corpus Of Contemporary American English (2012) lists 352 occurrences - and it can even be conjugated as in "to be bar mitzvahed". Hitchings (2009, p. 258) quotes it as an example among others of "elements of Yiddish [that] are widely known across the Englishspeaking world", with words like bagel. It may sound as a well-integrated loanword, but, outside the USA, it is still listed as a culture-specific reference by Chiaro (2009, p. 157). Drawing on Katan (2004, p. 147), she relies on three main strategies for the translation of such CSRs, that is, hyperonymy, hyponymy and same-level equivalence, in this order.

In Scoop, however, a fourth option has been selected, and bar mitzvah has just been borrowed.

DV, Sid : Écoutez, moi, tout ça, ça n'me regarde pas, Sondra. C'est pas mon truc, moi. Moi, moi, j'fais les bar mitzvahs, les fêtes, les anniversaires pour les gosses...

In her translation, Cohen was guided by several levels of analysis. First, she estimated that the ceremony can nowadays be identified by Frenchspeaking audiences, ${ }^{3}$ and the full sense of the lexical unit is also made 
obvious thanks to the multiple clues offered by the audiovisual context constructed by Allen. The sequence happens in London, after a scene where Sid had stressed that Sondra Pransky and he share Jewish origins, stating she comes from Brooklyn like himself, and mistakenly calling her Ms Mandelbaum. When she corrects him, he answers:

OV, 13', Sid: Pransky, Mandelbaum, listen, you take off the same holidays, it doesn't matter!

DV, Sid: Pransky, Mandelbaum, ben quoi, oui, vous avez les mêmes jours de fête, c'est pareil!

The allusion to the religious holidays linking both names is a way of focusing the attention on the Jewish background of the heroine. As a result, the occurrence of bar mitzvahs later on in the script is no surprise for the audience. Just like in the case of seder, the spectators hear a dialogue in which "the non-translation of a term can be valued as an eminent mode of translation" (Berman, 1984, p. 302). They are helped by the contextual circumstances of the plot, whether it be the visual setting or the information delivered in the preceding lines. Nevertheless, the situation is not always so easy to deal with for the translator.

\subsection{Yarmulke}

Deconstructing Harry (1996) presents an example of the use of yarmulke, a Yiddish synonym of the Hebrew kippah. The lexeme is rather common in American, - up to 179 occurrences of the word are offered in the COCA. When Harry's sister gets exasperated by his cynicism regarding their family's religious persuasion, she exclaims:

OV, 59'45, Doris: Yeah, wait'll he gets cancer. He'll be the first one in synagogue sitting in the front row in a yarmulke.

Yarmulke is not an ordinary piece of clothing, as it bears strong religious connotations. However, the French dubbed track does not preserve the word in the re-recorded dialogue.

$D V$, Doris : Mais quand il aura un cancer, on va l'voir courir à la synagogue pour faire ses prières, au premier rang.

French has not borrowed yarmulke from the Yiddish and the dubber ${ }^{5}$ chose to use praying as an equivalent for wearing a yarmulke. The religious symbolism is thus rendered explicitly, but the original item is not mentioned. The French audience would have found it all the more difficult to understand the lexeme as it remains an extra-diegetic reference, since the yarmulke is not visible onscreen. This translation 
choice was made by the dubbing studio and not by Cohen, who had opted to combine the loanword with an explicitation, as can be seen in the published script (Allen, 1998, p. 133).

JC, Doris: Attends qu'il ait un cancer! Il sera le premier à la synagogue à faire ses prières, au premier rang, avec son yarmulke.

These diverging options are a reminder of the way the dubbing process works: it is a team project implying a chain of intervening parties who can influence the final production at every step.

In a different context, borrowing would have been much easier, for instance in Hollywood Ending (2002), whose stage directions were translated as follows in the bilingual edition of the script:

OV (p.106): Al enters, still wearing his yarmulke, walks into the living room.

JC (p. 107) : Al entre dans le salon. Il porte encore sa Kippa.

Cohen did not keep the Yiddish word, but offered its Hebrew equivalent, a much better integrated loanword which helped maintain the exotic touch wanted by the director without Frenchifying the reference. Multilingualism was then preserved.

\subsection{Tallith}

In a flashback episode from Annie Hall (1977), the adult Alvy goes back to his childhood classroom. There he meets his own child self among his classmates and tries to know what has become of them.

$$
\text { OV, 5'10, 2nd Boy: I sell tallises. }{ }^{6}
$$

A tallith is a "woolen or silk (...) shawl with fringes at the 4 corners and black or blue stripes at the ends that is worn over the head or round the shoulders by orthodox and conservative Jewish men and boys over 13 usu. during morning prayers" (Webster's, 1966, p. 2334). This Hebrew word has not been assimilated by French, so it is ambiguously rendered in the dubbed version written by Georges Dutter, who translated Allen's films from 1977 to 1987.

\section{DV, $2^{e}$ garçon: Moi, je vends des calottes.}

The problem with the French lexeme calotte lies in its polysemy. It can mean skullcap, which would only be a loose equivalent of tallith as it does not refer to the same religious garment, but it can also be understood as a slang word for slap. Bearing no obvious Jewish connotation, the line 
may prove almost incomprehensible for a French viewer; it certainly would have, some forty years ago. Borrowing the word or offering an equivalent such as kippa would probably have been less disturbing for the audience, because the Jewish connotations would have been preserved and the ambiguity induced by the polysemy of calottes would no longer have altered the line.

\subsection{Rituals and religious laws}

It comes as no surprise that translating Jewish religious references into French is all the more difficult when they cannot be seen onscreen, as shown in the last three examples above. Both Dutter, interviewed in 2012, and Cohen, in 2011, insisted on the advantage represented by their Jewish marriage (Dutter's wife, Anne Domela, translated films with him, even if she was not always credited) or descent (Cohen explained she turned to her grandmother when she needed help with Yiddish words), to grasp the meaning of certain references.

Indeed, there was a time when the presumed restricted knowledge of Jewish traditions by French spectators was such that, for Everything You Always Wanted to Know About Sex... (1972), the anonymous adaptor chose an extensive explicitation for the following line, spoken by a TV host describing the parodic game played in his show, What are Sex Perverts?:

OV, 56'15, Jack: While at the same time, Mrs Baumel, the rabbi's wife, whom we've flown in from Indiana... will sit at the rabbi's feet... and eat pork!

Here is what the French spectators could hear:

DV, Jack : Et pendant ce temps-là, madame Baumel, la femme du rabbin, va s'agenouiller aux pieds de son mari pour manger des côtelettes de porc, ce qui, vous le savez, est strictement interdit dans la religion israélite!

Technically speaking, the addition is made possible by the omission of the relative clause "whom we've flown in from Indiana..." and by the fact that the speaker is only heard in voice over, which entails no synchronization constraint. The initial line is completed with a reminder of the Jewish dietary law: “... eat pork, which, as you know, is strictly forbidden in the Jewish religion". "As you know" offers a hint of dramatic irony, as it contradicts the translator's strategy based on the assumption that the spectator is ignorant of the observance.

This strategy has to do with what Steiner (1998) calls "preinformation" (p. 11): "Dealing with the problem of necessary and 
sufficient context, with the amount of prior material required to understand a given message unit" (p. 11). In the French soundtrack of All You Wanted..., the dubber has added the pre-information seen as necessary to render the religious allusion for the spectator.

If such an explicitation was deemed indispensable for so basic a Jewish ritual, one can imagine the stakes represented by Yiddish loanwords for French translators. All the more as it adds to another prejudice most common among dubbing adaptors:

Expected low mass audience comprehension of cultural diversity has often been posited as the explanation for consistent reductionist translational strategies (...) in an attempt to widen the appeal of "art" films in the target culture (Denton, 1999, p. 46).

Translators have to gauge the different degrees of foreignness of such loanwords in the source and target languages, and this can only be a subjective appreciation.

\subsection{Yom Kippur}

Sometimes multilingualism can, on the contrary, be reinstated onscreen, as in Radio Days (1987), where explicitation is achieved thanks to a loanword, supposedly more understandable than the American English source phrase. In the scene, filmed in a medium close shot, Tess is fulminating against her neighbors who feast on a Jewish holiday when they should be fasting, repenting and praying.

OV, 23'30, Tess: You think they fast? They don't care about the High Holidays. They eat, even though you're supposed to fast. $D V$, Tess : Tu crois qu'ils jeûnent? Ils se fichent éperdument du Yom Kippour. Ils mangent même quand en principe on doit jeûner.

A literal translation of High Holidays into French, "grandes vacances", would back-translate as "summer holidays" and Tess's line would thus become incomprehensible. Therefore, an equivalent was chosen, the French transliteration of Yom Kippur. This is only the last of the ten High Holidays, yet the most solemn one as it is observed even by secular Jews who do not otherwise comply with religious requirements. The translator's option helps render the general local color infused in the movie, which is set in Rockaway in the 1940s and obviously based on Allen's childhood memories-he plays the voice-off narrating the story. The strategy agrees with Eco's observation (2003): “(...) translating is like performing a dialogue with Another One, ${ }^{7}$ and in every dialogue one tries to understand the point of view of the interlocutor" (pp. 124-125). 
Even though these uses of Yinglish pose translation problems, we have seen that their transfer into French has become more common practice over the years, and words for rituals that needed long explicitations in Allen's early films in the 1970s were often borrowed in the 1990s and 2000s. Their degree of foreignness has dramatically weakened in the past decades as the contacts between civilizations have continued to intensify in the context of globalization, and the dubbing technique can even help this assimilation process by adding the required pre-information for the French audience when deemed necessary.

There remains another class of Yinglish lexicon much more difficult to dub yet, even in more recent movies by Allen, that is, the slang register, for "Yiddish abounds with pungent denominations for people" (Hitchings, 2009, p. 259). Such lexical items can obviously be expected in the dialogues written by Allen, where dramatic climaxes are often built up by the progression of interpersonal interactions.

\section{Slang and affective borrowing}

Allen is known for his predilection for irony and self-derision. These features often rely on double entendre involving comical ambiguity, but the director also resorts to Yiddish slang and taboo speech. These registers can prove most arduous to translate.

American films pose particular problems for dubbing because the country has so many different ethnic and social groups and such a propensity for slang, some of it incomprehensible even to many American viewers (Zatlin, 2005, p. 142).

The comprehension of this particular lexicon being sometimes limited even in the original audience, transferring it into a third language is indeed a challenge, as can be seen in the following examples.

\subsection{Meshugana}

Let us consider the noun meshugana, derived from the adjective meshugah or meshuge, which Hitchings (2009) puts in the category of "expressive adjectives -an unusually high percentage of borrowings from Yiddish are adjectives-" (p. 259). This synonym of crazy has an altered form found in the dialogues of Deconstructing Harry (1996), when Harry answers his former lover, who is threatening him with a gun.

OV, 11', Harry: Look, I'm not going to stand up here on this fucking roof, eh, with a, a world class meshugana cunt and beg for my life. 
The word is well established in American, though its spelling can vary; it is listed in Webster's (1966, p. 1416), which defines it as "mentally unbalanced", and Marckwardt (1969, p. 56) states that many urban dwellers are able to recognize it, whatever their socio-ethnic origins. However, its meaning will remain elusive for non-English speakers. Baxter (1999), one of Allen's biographers, thus relates a comment made by Kurt Andersen:

Jane Campion, the head of the Venice jury, told me she liked Woody Allen's Deconstructing Harry, although for the overwhelmingly Italian audience phrases like 'world-class meshugannah ${ }^{8}$ cunt' probably lost something in translation (p. 1).

The problem is the same for French viewers, and led to this dubbed version:

DV, Harry: Écoute... j'ai pas l'intention de rester planté sur ce putain de toit toute, toute la nuit... à supplier la reine des médailles d'or des, des folles dingues de m'épargner.

As a result, the Yiddish etymology of the adjective has disappeared from the French dubbing, which back-translates as "nutcase" or "screwball". It sounds less offensive than the original, especially as "cunt" has been deleted in translation. This strategy can be identified as one of cultural substitution, and it modifies the perception of the scene by the spectators, for loanwords are very often a way for the author to hide, or on the contrary, to promote a taboo word. ${ }^{9}$ Yiddish is very prone to hyperbole (Emblidge, 1977, p. 111), and here, using a Yinglish adjective reinforces the vulgarity of the line, already heavy-loaded with the occurrences of "fucking" and "cunt" in the co-text. Multilingualism is indeed a deliberate stylistic choice of the author of the film, an idiosyncrasy which gets lost on the dubbed track, even though Cohen had opted for another strategy, closer to the original version (Allen, 1998, p. 31).

JC, Harry: Écoute... j'ai pas l'intention de rester planté sur ce putain de toit à supplier la reine des médailles d'or des «meshuganas » [mot yiddish] de m'épargner.

\subsection{Mensch}

Yinglish also offers some less offensive vocabulary, as in the example heard in Crimes and Misdemeanors (1989), when Cliff offers his opinion on Rabbi Ben: 
OV, 62'20, Cliff: He's a wonderful guy. The poor guy called me last night. He's going blind. He's got a terrible eye disease and he's losing his sight. He's gonna be blind in another few months. But he's got a great attitude. He's really a mensch.

Mensch is registered 121 times by the COCA under this spelling and four times with the spelling mensh, mainly in fiction works (36\%) and in spoken material (21\%). Its meaning has evolved over time: "the Yinglish mensch, which originally meant 'man' (...) now denotes a person of uncommon maturity and decency" (Pinker, 2008, p. 120). The loanword is well integrated into American English, but it is a true foreignism for French-speaking audiences. Therefore, they are offered the following dubbed version:

DV, Cliff : C'est un type formidable, hein. Il m'a appelé hier soir. Il va devenir aveugle. Oui, il a une terrible maladie des yeux, hein, il perd la vue. Il sera complètement aveugle dans quelques mois. Mais il a une force de caractère! Ça, ça c'est... ça c'est un homme!

The dubber returns to the original sense of the noun, the hyperonym man, which does not render the qualities emphasized by Cliff in the original soundtrack of the movie, even though the intonation pattern (transcribed by the use of the exclamation mark here) works as a compensation device in French. This entails a transfer of responsibility from the translator to the dubbing actor.

It should be noted that, through intonation, stress and volume, the voice of the dubbing actor can compensate, to a certain extent, for meaning which has been changed or lost (Pettit, 2005, p. 62).

In the present case, the choice of a French equivalent was a decision made by the dubbing director, although Cohen had proposed to keep the Yiddish noun. When we interviewed her in 2011, she argued that "mensch could have been kept in the French version, because it is a German word, and moreover, the overall context is clear." In her mind, the foreignness of mensch, as a Germanism, justified her strategy of not translating it. However, multilingualism eventually got lost here. 


\subsection{Palooka}

Going back in time to Radio Days (1987), the fond memories of Allen's childhood induce some day-to-day bickering, such as in this line by Joe's father about his son:

OV, 32'10, Father: (about Joe) This palooka can't even pass a simple arithmetic exam.

A palooka is defined as "1. an inexperienced or incompetent boxer", and "2. a clumsy inept person" (Webster's, 1966, p. 1627). These definitions help trace the evolution of the noun, which was first used by sports commentators and is now applied to any foolish person. The extension of its meaning is such that the original sense is only a hyponym now, and the metaphorical use has taken over. This diachronic phenomenon is very common with foreignisms. When assimilated by a foreign language, loanwords are estranged from their original cultural context and references. "All context is diachronic and the field of meaning, of tonality, of associative range is in motion" (Steiner, 1998, p. 352). In addition, in the above example, dubbing favors labial synchronism, for the father is filmed in a medium close shot:

$D V$, Le père : Ah, ce pignouf, là, il sait même pas faire une simple opération de calcul mental.

Pignouf is folk language, officially registered in French since 1857. It applies to boorish or loutish individuals and it carries pejorative overtones, so it remains coherent with the register and the meaning of the original lexical unit. However, once again, its Yiddish etymology has been erased from the dialogue. Of course, in dubbed films, multilingualism does not rely on lexical tools exclusively. The father speaks French with a mock stereotyped intonation, ending with a sarcastic interrogative tone which reminds of his ethnic origins. The interlingual variation that could be heard in the original movie has become intralingual in the dubbed one, as it now relies solely on prosody.

\subsection{Putz}

In Deconstructing Harry (1996), Harvey is mistakenly trapped by Death while staying at the flat of his friend Mendel and even wearing his bathrobe.

OV, 15’25, Harvey: No, stop calling me Mendel. Please, I'm just using his pad. 
Death: Right. They always have an excuse. Let's go... move it, you, little putz.

According to Thorne (2007), putz is used for "a foolish, clumsy or unfortunate person" (p. 351) and its etymology is openly sexual as "the word is the Yiddish for 'ornament', used as a synonym for the male member" (p. 351). The COCA records 61 occurrences of the common noun, which means it is well integrated in American English. Thorne (2007) also states: "Despite its (little-known) origin, putz is a relatively mild term of abuse in English; in Yiddish it still carries more pejorative overtones" (p. 351). Once again, a semantic shift has occurred in the process of turning the Yiddish lexeme into Yinglish. The French dubbed version of Deconstructing Harry offers no hint of its ethnic origins.

DV, La Mort : Mais oui! Ils ont toujours une bonne excuse! En route! Magne-toi, trouduc.

Cohen has maintained the overall vulgarity and the scatological register of the injunction, given that trouduc back-translates as asshole. However, multilingualism has disappeared once more, and the network of Yiddish loanwords in the film is seriously impacted: out of the six occurrences from this same movie considered here, only two are maintained in French. The comparative analysis thus confirms Chaume's (2007) view that "dubbing is in itself a domesticating kind of translation" (p. 213). We illustrate this with one last example below.

\subsection{Schmuck}

Schmuck is one of the most common Yiddishisms in American. The COCA offers 212 occurrences under the spellings schmuck and shmuck, while Webster (1966, p. 2030) also lists it under the entries schmo, shmo or schmoe, as a synonym of jerk. Like putz, "in Yiddish the word was first used as a euphemism for the male member, it then became a synonym for the English "prick", figuratively as well as literally" (Thorne, 2007, p. 378). It was first borrowed from the German noun shmuck (adornment or jewel). As Hitchings (2009) points out, "it's not hard to see how this became a slang term for a man's favourite pendant, and any word for the penis sooner or later becomes a term of abuse" (p. 259). This metaphorical process is well known.

Yet, when shifting from its original meaning, the lexeme lost its most violent connotations and has "entered into wide usage that simply overlooks [its] taboo status." (Bluestein, 1998, p. xxxi). The toning down can be explained by two factors. First of all, the appreciation of decency is relative and continually moving: "The spectrum of permissible expression as against that which is taboo shifts perpetually" (Steiner, 
1998, p 19). Regarding schmuck, the word was even used for the title of the American adaptation of Le diner de cons (1998), a French comedy which became Dinner for Schmucks in 2010.

Gold (2002, p. 116) also underlines another phenomenon, i.e. the ironic connotations associated with the onset shm- in American, even though the Yiddish original lexemes do not always carry such overtones. This submorphemic iconicity - Hitchings (2009, p. 259) calls the sch sound "dismissive" - means that phonæsthemes should not be ignored onscreen, where the oral dimensions of dialogues add significant layers of meaning for the audience, most of all when they produce that same effect in the target language, as is the case with French. ${ }^{10}$

Nevertheless, these phonetic characteristics disappear in most dubbed versions of Allen's films. Let us first consider Manhattan, in 1979.

OV, 14'25, Mary: I mean, they're such schmucks up there. (Chuckling) Really mired in thirties radicalism.

Mary, a journalist, is criticizing the reporters of a marginal magazine, and she feels compelled to set herself apart. In the dubbed version the line is translated by Dutter as follows:

DV, Mary: Franchement, ils sont tellement cons ces mecs! (elle a un petit rire) Ça barbote dans les années trente! Ça s'veut... extrémiste!

The adjective cons back-translates as fool or idiot. It is vulgar or even rude in French, depending on the context. Besides, like schmuck, its etymology is sexual, as it was first used to designate female genitals. On the semantic level, this translation choice is thus rather relevant. However, the Yiddish touch is erased from the dialogue, once more.

The same equivalent will be used some twenty years later, in Deconstructing Harry (1996), this time by Cohen, within a sequence staging a quarrel between Harry and Lucy, his sister-in-law and former lover:

OV, 7'20, Lucy: But it's all here... The poor shmuck country doctor, the violinist, her younger sister in Connecticut cheating with her husband...

DV, Lucy: Mais tout est dans le livre... le pauv' con d'médecin d'campagne et la violoniste, hein... et sa jeune sour dans l'Connecticut qui la trompe avec son mari!

This ethnocentric strategy also applies to another utterance heard in the same scene, though a different equivalent is retained: 


\section{OV, 5'55, Lucy: (offscreen) You shmuck! You bastard! \\ DV, Lucy : (off) Espèce d'ignoble salopard!}

Shmuck (spelled this way in the published script) is translated here as ignoble (base, vile, wretched), which is no longer an autonomous exclamation sentence, but serves as an intensifier for salopard, the French equivalent for "bastard". Even though the French qualifiers are rather rude, the erasure of Yinglish from the soundtrack alters the construction of inter-subjective relations between the characters.

The reduction of polyphony also induces another immediate consequence: "robbing the audience of their chance of understanding and even learning about other cultures, other lifestyles, other realities" (Scandura, 2004, p. 133), criteria which become secondary in dubbing. The trend can be observed in most forms of translation:

In translation the dialectic of unison and plurality is dramatically at work. In one sense, each act of translation is an endeavour to abolish multiplicity and to bring different world-pictures back into perfect congruence (Steiner, 1998, p. 246).

The paradoxical mission assigned to translators is first constrained by the diverging capacities of languages to assimilate new words. Thus, none of the Yinglish words studied above is listed in the French etymological dictionary the Nouveau Dictionnaire Étymologique Larousse (1980). Therefore, it could be argued that the distance between Yinglish and French proves irreducible. However, the trend towards "Frenchification" in Allen's dialogues can also be ascribed to what Morini (2006, p. 124) calls a compulsion to normalize in translation. It derives from the communication goal assigned to translators, but it becomes more evident still in polyphonic source-texts.

In the case of "doubly foreign" texts, the first question the translator asks him/herself is if that double foreignness is crucial to an understanding of the source (Morini, 2006, p. 125).

More often than not, this question is answered negatively, and the foreign touch gets erased (Baker, 2009, p. 25). In so doing, translation reduces the distance between the text and its receiver, yet it also diminishes its aesthetic and stylistic quality. This applies to written texts, but also to films. As a result, during the reception phase, the image of the Model Author $^{11}$ conveyed by the dubbed film may shift quite far from the original one. Of course, it must be stressed that French dubbing steers clear of the extremes dubbed versions in other countries sometimes go to, as is the case in the Italian dubbing of a scene from Allen's Sleeper (1973): 
The Italian dubbing actors replace the American-Jewish accent of the source text with a very strong Sicilian accent. All the Jewish cultural references (Passover, matzos, etc.) are changed accordingly into Sicilian references (Ranzato, 2011, p. 135).

This shows how contingent the appreciation of foreignness can be. The Model Addressee of a dubbed version is very different from the one designed by the original author. In such a context, it is not always easy to abide by recommendations such as: "The translator, in cooperation with the dubbing director and actors, nevertheless must still consider how to handle the linguistic aspects of local color, such as dialect and slang" (Zatlin, 2005, p. 142).

Yet the domestication process does not always take place during the translation phase itself. When interviewed in 2011, Cohen explained that, whenever she tried to maintain a Yiddishism in Allen's dialogues, it was deleted during the vocal re-recording session in the dubbing studio and replaced by a French equivalent, as shown in some of the examples discussed in this paper. Therefore, choices that under-estimate the audience may sometimes come from the technicians, the dubbing actors or the dubbing director, ${ }^{12}$ under the influence of distributors, rather than from the adaptors themselves.

\section{Conclusion}

This paper has focused on the circumstances under which Yiddish loanwords, that is, Yinglish, are translated or, on the contrary, preserved in the final French dubbed versions of some of Allen's movies. Yiddishisms are both cultural referents and stylistic devices. Erasing them during the dubbing process means that the translated film is poorer on a linguistic level. This also has an impact on the representation of American society portrayed onscreen, since the dubbing does not render the multiplicity of voices that can be heard in the American melting pot. Moreover, in the case of very personal films by Allen who is generally recognized as a true auteur, the whole impact of his witty dialogues can be modified, as well as the social and cultural setting he relies on, with its associated language, slang in particular.

Multilingualism appears to be more easily transferable in translation when it refers to technolectic items that can be seen in the visuals, as is the case with the religious lexicon in Allen's films. Out of the seventeen occurrences of the nine Yinglish lexemes presented in this paper, only two nouns, seder and bar mitzvah, are maintained in the French dubbed versions. Both concern Judaism rituals and have a Hebrew etymology, as does Yom Kippour, introduced in lieu of a more generic collocation, High Holidays. Dubbing thus operates as a major cultural mediation vector. 
When the original words are not transferred to the French version, the substitution process at the very core of dubbing may nevertheless allow the inclusion in the dialogues of some additional information aimed at the French spectators. However, multilingualism is mainly considered by dubbing directors and studios as an obstacle to communication, even when reduced to a few occasional words. The doubly foreign dialogues are therefore usually toned down or sacrificed in the target version, in an attempt to facilitate the audiences' comprehension.

We are dealing here with the ambiguity of authorship in audiovisual translation. Although a translator is credited for the final product, the scripts s/he produces may be modified several times before the dubbed movie reaches target audiences. The decision process is, thus, diluted, offering many opportunities for the deforming tendencies inherent to translation (Berman, 1984, p. 297) to operate. These affect multilingualism especially in the case of vernaculars, which end up being silenced more often than not (Berman, 1999, pp. 63-64). The same thing happens when the vernacular is part of what Berman calls "the superimposition of languages" (Berman, 1999, pp. 66-67), as evidenced by the Yinglish lexemes studied in this paper. This raises the issue of the ambivalence of film translation, dubbing in particular, walking on a tightrope between two fundamentally antithetical goals, that is, facilitating the spectators' task and preserving the foreign touch of the author's, - or auteur's — work.

\section{References}

Allen, W. (1998). Deconstructing Harry, Harry dans tous ses états, scénario bilingue. (J. Cohen, Trans.). Paris: Cahiers du cinéma.

Allen, W. (2002). Hollywood Ending, scénario bilingue. (J. Cohen, Trans.). Paris: Cahiers du cinéma.

Allen, W. \& Brickman, M. (2000). Annie Hall, scénario bilingue. (G. Dutter, Trans.). Paris: Cahiers du cinéma. (Original work published 1983).

Allen, W. \& Brickman, M. (2000). Manhattan, scénario bilingue. (G. Dutter, Trans.). Paris: Cahiers du cinéma. (Original work published 1979).

Baker, M. (1992/2009). In Other Words. Abingdon/New York: Routledge.

Baxter, J. (1998/1999). Woody Allen, a Biography. London: HarperCollins.

Berman, A. (1984). L'épreuve de l'étranger. Paris: Gallimard.

Berman, A. (1999). La traduction et la lettre ou l'auberge du lointain. Paris: Le Seuil.

Bluestein, G. (1989/1998). Anglish/Yinglish: Yiddish in American Life and Literature. Lincoln: University of Nebraska Press.

Bubel, C. (2008). Film audiences as overhearers. Journal of Pragmatics, 40 (1), 5571.

Chaume, F. (2007) Dubbing practices in Europe: localisation beats globalisation. Linguistica Antverpiensia NS, (6), 203-217. 
Chiaro, D. (2009). Issues in audiovisual translation, In J. Munday (Ed.), The Routledge companion to translation studies. (pp. 141-165). Abingdon: Routledge.

Cohen, J. (2011). Personal interview. Neuilly-sur-Seine.

Dauzat, A. Dubois, J., \& Mitterand, H. (1971/1980). Nouveau dictionnaire étymologique. Paris: Larousse.

Davies, M. (2012). Corpus of contemporary American English 1990-2012, Brigham Young University. Retrieved 9/10/2014 from http://corpus.byu.edu/coca/

Denton, J. (1999). Domestication vs foreignizing: Humour, cinema, translation and culturally embedded stereotype transfer. In F. Antoine \& M. Wood (Eds.), Humour, culture, traduction(s) (pp. 45-53). Lille: Université. Charles de Gaulle.

Dournon, J.-Y. (1996). Le dictionnaire des difficultés du français. Paris: Hachette.

Dutter, G. (2012). Personal interview. Paris.

Eco, U. (1992). Les limites de l'interprétation. (M. Bouzaher, Trans.). Paris: Grasset. (Original work published 1990).

Eco, U. (2003). Mouse or rat? Translation as negotiation. London: Phoenix.

Eco, U. (1985/2004). Lector in Fabula, le rôle du lecteur. (M. Bouzaher, Trans.). Paris: Le Livre de Poche. (Original work published 1979).

Emblidge, D. (1977). The sick/healthy humor of Lenny Bruce. Revue Française d'Études Américaines, 4, 103-114.

Gold, E. (2002). English Shmenglish: Yiddish borrowings into Canadian English. In S. Burelle \& S. Somesfalean (Eds.), Proceedings of the 2002 Annual Conference of the Canadian Linguistic Association (pp. 108-120). Montreal.

Harris, M. (2009, June 1). Twilight of the Tummlers. New York Magazine. Retrieved 9/10/2014 from http://nymag.com/movies/features/56930/

Hitchings, H. (2008/2009). The secret life of words: How English became English. London: John Murray.

Jauss, H. R. (1978/2010). Pour une esthétique de la réception. (C. Maillard, Trans.). Paris: Gallimard. (Original work published 1972-1974).

Katan, D. (2004). Translating cultures. Northampton: St Jerome.

Marckwardt, A. H. (1958/1969). American English. New York: Oxford University Press.

Mencken, H. L. (1919/1977). The American language. New York: Alfred Knoff.

Merriam-Webster Online Dictionary, Encyclopædia Britannica. Retrieved 9/10/2014 from http://www.merriam-webster.com/dictionary/

Mingant, N., \& Tirtaine, C. (2012). Global film and television industries today: An analysis of industrial and cultural relations. InMedia, 1. Retrieved 9/10/2014 from http://inmedia.revues.org/111

Morini, M. (2006). Norms, difference and the translator: Or, how to reproduce double difference. In E. Monti \& F. Regattin (Eds.), Revue des Littératures de l'Union Européenne, 4, 123-140.

Novak, W., \& Waldoks, M. (1981). The big book of Jewish humor. New York: HarperCollins.

Ornstein-Galicia, J. L. (1989). Linguistic patterns and devices in American Jewish humorous discourse. Meta, 34(1), 125-127. 
Ornstein-Galicia, J. L. (1992). Affective borrowing from Yiddish in colloquial American English: Diachronic and synchronic aspects - and translatability. Meta, 37(3), 451-464.

Pérez-González, L. (2007). Appraising dubbed conversation: Systemic functional insights into the construal of naturalness in translated film dialogue. The Translator, 13(1), 1-38.

Pettit, Z. (2005). Translating register, style and tone in dubbing and subtitling. JoSTrans, The Journal of Specialised Translation, 4, 49-65.

Pinker, S. (2007/2008). The stuff of thought. London: Penguin.

Ranzato, I. (2011). Translating Woody Allen into Italian: Creativity in dubbing. JoSTrans, The Journal of Specialised Translation, 15, 121-141.

Santamaria, L. (2010). The translation of cultural referents: From reference to mental representation. Meta, 55(3), 516-528.

Scandura, G. (2004). Sex, lies and TV: Censorship and subtitling. Meta, 49(1), 125134.

Steiner, G. (1975/1998). After Babel. Oxford: Oxford University Press.

Thorne, T. (1990/2007). Dictionary of contemporary slang. London: A\&C Black.

Tournier, J. (2004). Précis de lexicologie anglaise. Paris: Ellipses.

United Jewish Appeal, Federation of New York. (2012). Jewish community study of New York 2011 population estimates. Retrieved 9/10/2014 from http://www.ujafedny.org/get/196898/

Webster's. (1966). Third new international dictionary of the English language unabridged. Chicago, IL: Encyclopædia Britannica, Merriam-Webster.

Zatlin, P. (2005). Theatrical translation and film adaptation: A practitioner's view. Clevedon: Multilingual Matters.

\section{Filmography}

Aronson, L. \& Robin, H. (Producers), \& Allen, W. (Director). (2002). Hollywood Ending. United States: DreamWorks.

Aronson, L. \& Wiley, G. (Producers), \& Allen, W. (Director). (2006). Scoop. United Kingdom/United States: BBC Films.

Bender, L. (Producer), \& Tarantino, Q. (Director). (2009). Inglourious Basterds. United States: Universal Pictures.

Doumanian, J. \& Brick, R. (Producers), \& Allen, W. (Director). (1996). Deconstructing Harry. United States: Fine Line Features.

Greenhut, R. (Producer), \& Allen, W. (Director). (1987). Radio Days. United States: Orion Pictures.

Greenhut, R. (Producer), \& Allen, W. (Director). (1989). Crimes and Misdemeanors. United States: Orion Pictures.

Joffe, C. (Producer), \& Allen, W. (Director). (1972). Everything You Always Wanted to Know About Sex But Were Afraid to Ask. United States: United Artists.

Joffe, C. (Producer), \& Allen, W. (Director). (1973). Sleeper. United States: United Artists. 
Joffe, C. (Producer), \& Allen, W. (Director). (1977). Annie Hall. United States: United Artists.

Joffe, C. (Producer), \& Allen, W. (Director). (1979). Manhattan. United States: United Artists.

MacDonald, L. \& Parks, W. (Producers), \& Roach, J. (Producer/Director). (2010). Dinner for Schmucks. United States: Paramount Pictures.

Poiré, A. (Producer), \& Veber, F. (Director). (1998). Le dîner de cons. France: Gaumont Buena Vista International.

1 The mixed immigrant population is known as hyphenated Americans.

2 Abbreviations used: OV, original version, with reference to the timing of the line quoted, DV, dubbed version, JC, J. Cohen's translation of the script.

3 Jacqueline Cohen, personal interview, February 15, 2011.

4 Emphasis in the original quotation in French, my translation.

5 The word "dubber" in this article refers to anyone involved in the dubbing of the film, apart from the translator him/herself, when we know he/she had not proposed what can be heard in the final recorded version.

6 The word is spelled here as in the published script, as are all other examples discussed (see references).

7 Capital initials in the original quotation.

8 Spelling and italics in the original quotation.

9 See Tournier (2004, p. 157): "Replacing a taboo word by its foreign equivalent is also a way of avoiding its use." (Original quotation in French, my translation).

10 Comedian Popeck, for instance, makes an extensive use of the phonæstheme.

11 The concepts of Model Author and Model Addressee are defined in Eco (1985/2004, p. 82).

12 As noticed by Chaume (2007), "Dubbing studios have concentrated their efforts on acting, direction of actors, and lip-sync. (...) Unfortunately, translation has not been given a starring role in this process" (p. 215). 